\title{
ANALYSIS OF JURE LANDSLIDE DAM, SINDHUPALCHOWK USING GIS AND REMOTE SENSING
}

\author{
T. D. Acharya ${ }^{a}, *$, S. C. Mainali ${ }^{b}$, I. T. Yang ${ }^{a}$, D. H. Lee ${ }^{\text {a }}$ \\ Department of Civil Engineering, Kangwon National University, Chuncheon, Republic of Korea - (tridevacharya, intae, \\ geodesy)@kangwon.ac.kr \\ ${ }^{\mathrm{b}}$ Survey Office, Chautara, Sindhupalchowk, Nepal - scm.sharad@gmail.com
}

\section{Youth Forum}

KEY WORDS: Landslide, Dam, GIS, Remote Sensing, Jure, Nepal

\begin{abstract}
:
On $2^{\text {nd }}$ August 2014, a rainfall-induced massive landslide hit Jure village, Sindhupalchowk killing 156 people at a distance of $70 \mathrm{~km}$ North-East of Kathmandu, Nepal. The landslide was a typical slope failure with massive rock fragments, sand and soil. A total of estimated 6 million cubic meters debris raised more than $100 \mathrm{~m}$ from the water level and affected opposite side of the bank. The landslide blocked the Sunkoshi River completely forming an estimated 8 million cubic meter lake of $3 \mathrm{~km}$ length and 300-350m width upstream. It took nearly 12 hour to fill the lake and overflow the debris dam. The lake affected five Village Development Committees (VDC) including highway, school, health post, postal service, police station, VDC office and temple upstream. The bottom of the dam was composed of highly cemented material and the derbies affected Sunkoshi hydropower downstream. Moreover, it caused the potential threat of Lake Outburst Flood. The lake was released by blasting off part of the landslide blockade and facilitated release of water from the lake. With the help of Remote Sensing (RS), series satellite images were used to identified, compared with previous state and quick estimation of potential treat was analysed. Using geographic information System (GIS) technology, estimation of volume, affected households, service centres, parcels etc. in the area was possible. In such hilly regions where disaster are very frequent, using GIS and RS technology comes very handy for immediate planning and response.
\end{abstract}

\section{INTRODUCTION}

Nepal is one of the most vulnerable countries to disaster due to its active tectonics, fragile geology, steep topography and climatic uncertainties. These disasters not only cause massive loss of life property annually but also hinders the economic development of the nation.

Landslides are very often disaster that occur in hilly and Himalayan regions of Nepal. Most of the events are induced mostly by the heavy and prolonged rainfall, but recent human activities such as improper land use, encroachment into vulnerable land slopes and unplanned development activities such as construction of roads and irrigation canals without proper protection measures has aggravated the risks (Petley, Hearn et al., 2007). Apart from massive landslides in Nepal, occurrences of many small-scale landslides in remote areas are seldom accounted unless they involve the loss of life. Also, the economic losses caused by small-scale landslides are no less than any other big event of natural disaster (Dahal, 2012).

Even though landslide events are uncertain, with the integrated application of GIS and RS with other datasets provides tremendous potential for identification, evaluation, monitoring and management of these events (Jianzhong, Fenqin et al., 2011, Pradhan, 2011, Pradhan, Lee et al., 2010). RS technology immediately provides surveying of topography and monitoring of a landslide event. GIS technology has powerful spatial analysis function, which can analyse the data extracted from RS, understand relationship with other related data and extract relevant information in order to make scientific decision- making basis for the calculation of current loss and further planning prevention and mitigation measures.

In this study, a case study of Jure landslide, a massive landslide event in Araniko highway, Nepal has been explored for the application of GIS and RS technology in disaster response. It focus on quick estimation of potential treat such as estimation of area and volume, affected households, service centres, parcels etc. after the event.
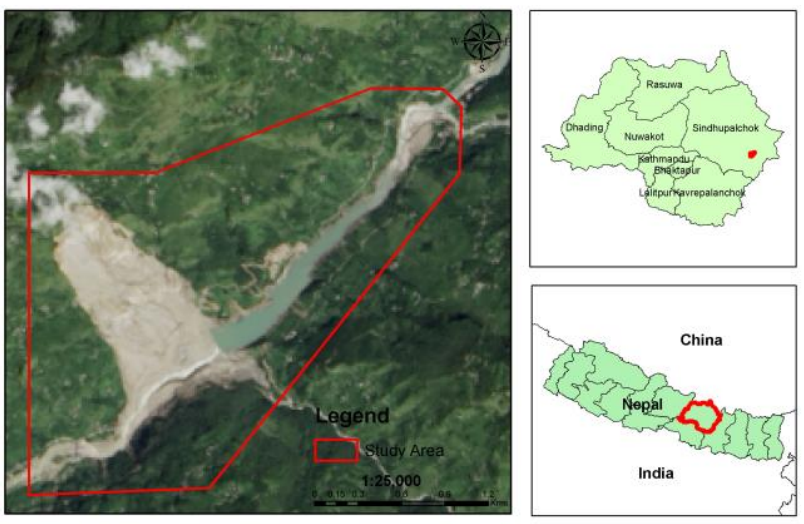

Figure 1. Location Map of Jure Landslide with Landsat 8 image acquired on September 18, 2014. (Source: USGS)

\footnotetext{
* Corresponding author
} 


\section{STUDY AREA, EVENT AND DATA USED}

\subsection{Study Area}

The study area lies in Sindhupalchowk district in the central region of Nepal It is $70 \mathrm{~km}$ away to the north-east of Kathmandu valley and lies between $27^{\circ} 45^{\prime} 19.75^{\prime \prime} \mathrm{N}$ -

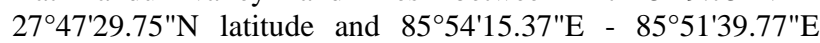
longitude. The overall terrain of the study area is hilly ranging with river passing through them. Araniko highway passes through the area along the Sunkoshi river side connecting to China boarder at Kodari. The climate is subtropical, temperate, and alpine. The temperature range is $28.5^{\circ}$ to $4.0^{\circ} \mathrm{C}$ and rainfall is $3604.3 \mathrm{ml}$ of which $80 \%$ fall in monsoon season (Nepal Tourism Board 2008). The geology of the area is very active and has Kuncha formation which is light green-grey phyllites, phyllitic quartzites and meta-sandstones, fine grained quartzconglomerates and rare basic (amphibolitic) volcanic layers. Large landslides have occurred frequently in the area at different intervals of time.

\subsection{Study Event}

On $2^{\text {nd }}$ August 2014, at around 2:36 am, a rainfall-induced massive landslide hit Jure village, Sindhupalchowk killing 156 people. It is located at $27^{\circ} 46^{\prime} 1.55^{\prime \prime N}$ latitude and $85^{\circ} 52^{\prime} 17.10^{\prime \prime} \mathrm{E}$ longitude. The landslide was a typical slope failure with massive rock fragments, sand and soil. It deposited large volume of debris on the Waterway of Sunkoshi River and blocked it. It took nearly 12 hour to fill the lake and overflow the debris dam and, lead to the potential threat of Lake Outburst flood. The lake was released by blasting off part of the landslide blockade and facilitated release of water from the lake.
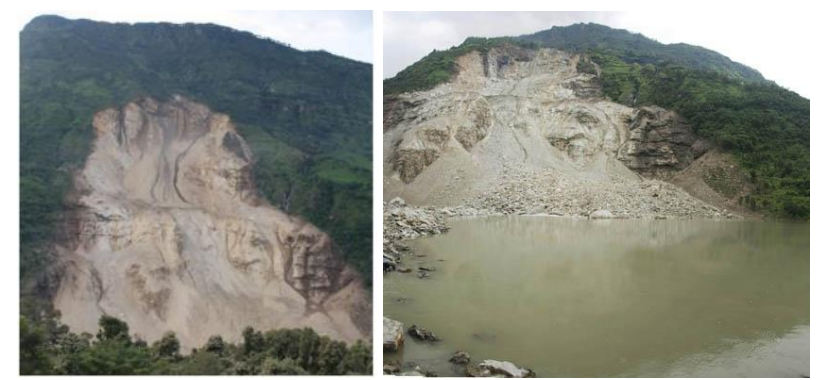

Figure 2. Jure landslide ground view (left) and lake formed by debris (right). (Source: Internet)

\subsection{Data used}

For the study, the following data has been used for the immediate response and estimation of attributes related to landslide event:

1. Satellite Imageries from Google Earth and USGS for identification and monitoring of landslide event and its lake formation.

2. Topographic Map of Sindhupalchowk district for the identification of infrastructure damage.

3. Cadastral Map of VDCs provided by survey office of Sindhupalchowk to identify the damaged land parcels.

\section{ANALYSIS USING GIS AND RS}

GIS and RS goes hand in hand in case of any geospatial problems. RS provides immediate overview through imageries which are used to create input data for GIS, whereas GIS with its powerful tools and techniques allows to extract various information and also visualize in the form of maps.

In case of Jure Landslide event, a quick view of past imagery from USGS Landsat archive or Google Earth showed that the site has multiple old landslides and was very vulnerable. Following figure 3 shows the pre and post satellite view of landslide event.
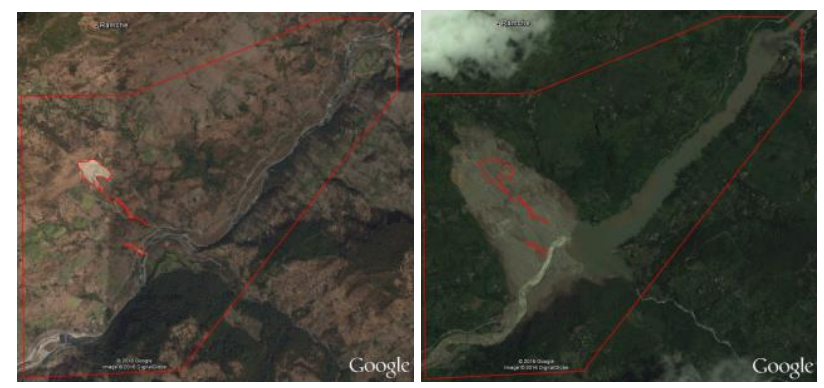

Figure 3. Google Earth view pre landslide acquired on Nov. 10,

2013 (left) and post landslide acquired on August 10, 2014

(right) landslide event with old landslide polygons.

Using high resolution imagery provided in Google Earth all necessary polygons and length measurements were done. Figure 4 shows the measurement done for the disaster. A total of estimated 6 million cubic meters debris fall from $11762 \mathrm{~m}$ tall and 717,218 $\mathrm{m}^{2}$ chunk of hill raised more than $100 \mathrm{~m}$ from the water level and affected opposite side of the bank. The width of the top of landslide was around $491 \mathrm{~m}$ and base 725 on approximation. Similarly, the deposition on the opposite river bank was $533 \mathrm{~m}$ wide and area of $130,368 \mathrm{~m}^{2}$. The landslide blocked the Sunkoshi River completely forming an estimated 8 million cubic meter lake approximately $3 \mathrm{~km}$ length and 275 $150 \mathrm{~m}$ width upstream.

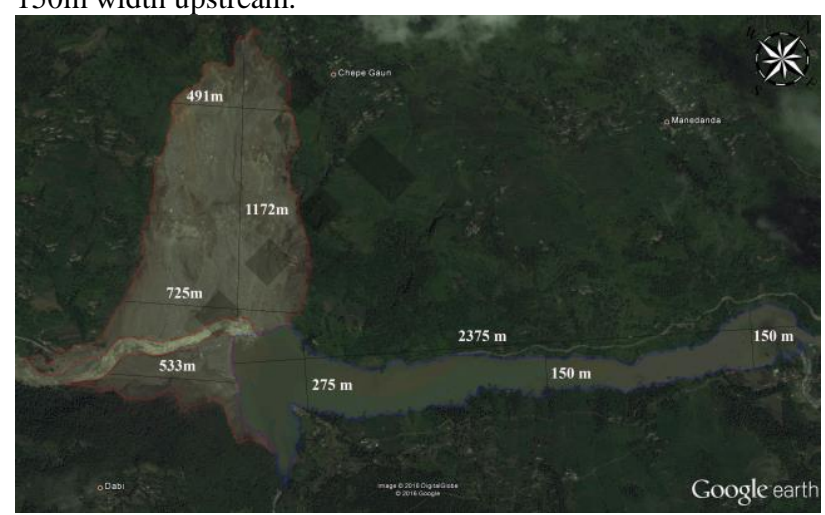

Figure 4. Measurements of Landslide characteristics using Google Earth

After the extraction of all the characteristics of landslide, the features were overplayed with topographic and cadastral map for the analysis of damage in the area. The lake affected five VDCs namely Kalika, Kadambas, Yamuna Dada, Pulchodanda and Thumpakhar. With available 5 cadastral sheets of the affected area, a total of 631 parcels were affected by the slide or by the lake formed. The landuse map of the affected parcels is shown in Figure 5, of which most affected is cultivable land and steep slopes and forest area. 
The landslide affected directly the Araniko highway, at least a total of $2 \mathrm{~km}$ and blocked the road and cut off two sides. Services centres like school, health post, postal service, police station, VDC office and temple were affected in the upstream. The bottom of the dam was composed of highly cemented material and the derbies affected Sunkoshi hydropower downstream.

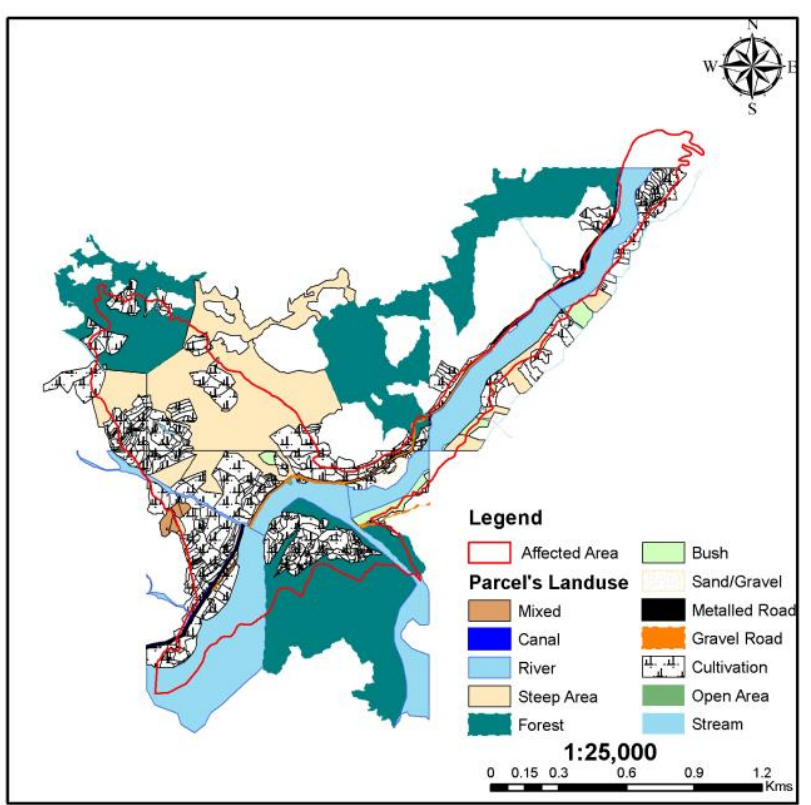

Figure 5. Landuse map of affected parcels in Jure Landslide

\section{CONCLUSIONS AND RECOMMENDATIONS}

In hilly regions of Nepal, large landslides are very common and have already occurred in various places in different intervals of time. The situations are similar in many other parts as well and are very vulnerable. In this work, we applied GIS and RS for the immediate determination and understanding of the Jure landslide event occurred in central Nepal. The study is limited to availability of proper and updated data.

Further works require to analyse more recent remote sensing techniques as well as more update databases in GIS environment.

\section{REFERENCES}

Dahal, R.K., 2012. Rainfall-induced Landslides in Nepal. International Journal of Erosion Control Engineering, 5(1), pp. $1-8$.

Jianzhong, Y., Fenqin, H. and Zhibing, L., 2011. Researching the Relationships between the Environmental Change of Vegetation and the Activity of Debris Flows Based on Remote Sensing and GIS. Procedia Environmental Sciences, 11, Part B, pp. 918-924.

Nepal Tourism Board, 2008. Tourism Products of Nepal. Kathmandu: Nepal Tourism Board 2008.

Petley, D., Hearn, G., Hart, A., Rosser, N., Dunning, S., Oven, K. and Mitchell, W., 2007. Trends in landslide occurrence in Nepal. Natural Hazards, 43(1), pp. 23-44.
Pradhan, B., 2011. Manifestation of an advanced fuzzy logic model coupled with Geo-information techniques to landslide susceptibility mapping and their comparison with logistic regression modelling. Environmental and Ecological Statistics, 18(3), pp. 471-493.

Pradhan, B., Lee, S. and Buchroithner, M.F., 2010. Remote Sensing and GIS-based Landslide Susceptibility Analysis and its Cross-validation in Three Test Areas Using a Frequency Ratio Model. Photogrammetrie - Fernerkundung Geoinformation, 2010(1), pp. 17-32. 